\title{
Estimation of Waste Generation and Recycling Potential from Traditional Market: A Case Study in Hue City, Vietnam
}

\author{
Yasuhiro Matsui ${ }^{1}$, Do Thi Thu Trang', Nguyen Phuc Thanh ${ }^{2}$ \\ ${ }^{1}$ Graduate School of Environmental and Life Science, Okayama University, Okayama, Japan \\ ${ }^{2}$ Hitachi Zosen Corp, Osaka, Japan \\ Email: matsui@cc.okayama-u.ac.jp, dothithutrang209@gmail.com, nguyen p@hitachizosen.co.jp
}

Received 12 January 2015; accepted 10 April 2015; published 13 April 2015

Copyright (C) 2015 by authors and Scientific Research Publishing Inc.

This work is licensed under the Creative Commons Attribution International License (CC BY). http://creativecommons.org/licenses/by/4.0/

\section{Abstract}

This study was conducted to provide a detailed description of waste generation and characteristics from a traditional market in Hue city, located in central Vietnam. The authors conducted a waste generation survey and a waste composition survey for 309 stalls/vendors in five markets by 17 business categories for 10 consecutive days. The waste generation rates by stall/vendor and by floor area were assessed in three waste categories: general waste, recyclable, and food residues. The general waste that would be sent to a landfill site was classified into 10 physical categories and 77 sub-categories. For general waste, food waste accounted for the largest part, followed by plastic and grass. By multiplying the waste generation rate by stall/vendor by the total number of stall/vendors in $\mathbf{2 3}$ markets, the authors estimated the total amounts of general waste, recyclable, food residue and total waste by business category. The total waste generated from market was 17.0 tons/day, of which 4.6 tons $(27.1 \%)$ were collected by pig farmers for feeding livestock and 0.6 tons (3.6\%) were sold to the recycling market. The composting potential accounted for $55.2 \%$ of total waste generation from the traditional market in Hue. The recycling potential accounted for $\mathbf{5 . 1 \%}$. The total disposal amount sent to the landfill site would be reduced from $69.2 \%$ to $8.8 \%$ of the total. The 95\% confidence interval (CI) of total waste amount from 23 markets was also estimated using Monte Carlo simulation based on the mean and standard error of the waste generation rate. The range of $95 \%$ CI was 14.9 - 18.9 tons/day.

\section{Keywords}

Traditional Market, Recycling Potential, Composting Potential 


\section{Introduction}

In economically developing countries, the amount of municipal solid waste is approaching the capacity of existing waste facilities. It is impossible to continue waste disposal that is heavily dependent on landfill. Central and local governments must develop solid waste management (SWM) plans that include waste reduction and recycling.

Municipal solid waste is a growing problem in Vietnam, which is showing rapid economic growth year by year. Vietnam produces over 15 million tons of municipal solid waste each year from various sources. More than $80 \%$ (12.8 million tons/yr) derives from municipal sources: households, restaurants, markets, and businesses [1]. As the first step in designing integrated waste management systems, it is indispensable to ascertain detailed and reliable information related to waste generation, waste composition, and waste streams [2]. However, Vietnam lacks reliable and detailed data related to SWM. The latest report on SWM in Vietnam published in 2011 presented information related to overall waste generation and physical composition of MSW around Vietnam, but did not clarify details related to waste generation from different sources or details related to waste composition such as recycling or composting potential.

Regarding the municipal solid waste sources, traditional markets are known to be a considerable source of waste generation in economically developing countries. One earlier study [3] found that markets contributed about $20 \%$ of total waste generation in Indonesia. According to the Vietnam Retail Association, traditional markets still constitute the major channel of the retail sector. About 8550 traditional markets existed in Vietnam in 2011. However, few studies have specifically examined wastes from traditional markets. In Lao PDR, Byer et $a l$. [4] surveyed one early morning market (EMM), and clarified the waste generation rate by six business categories: fruits and vegetables, packaged goods, meat/fish/eggs, food stalls, noodles and blood, rice, and charcoal. They assessed the physical composition, but reported no potential for recycling and composting. In Cambodia and Vietnam, two surveys [5] [6] have assessed the waste generation rate by the total waste amount divided by the total number of stalls in target market, but they did not address differences in waste generation rates among business categories.

This study was undertaken to present a detailed description of waste generation and characteristic of traditional market in Hue city, Vietnam. The authors chose five markets from three market classes, and allocated the targets by 17 business categories considering "The System of Economic Branches of Vietnam". The authors also estimated the total waste amount, the recycling and composting potentials from all markets in Hue as the basis of rational SWM planning including waste reduction and recycling.

\section{Methodology}

\subsection{Research Area and Target Traditional Markets}

Hue city, the latest imperial capital of Vietnam under the Nguyen dynasty, is located in the central region of Vietnam [7]. Hue city comprises 27 wards with area of $71.69 \mathrm{~km}^{2}$ and a population of 350,345 people. There are two distinct seasons in Hue city: the dry season comes with the hot southwest wind for four months during April-August; the rainy season comes with high and unevenly distributed rainfall during September-March [8].

Regarding solid waste management, the amount of collected waste in Hue city is reported as approximately 210 tons/day. The general collection rate in the whole city was about $89 \%$, and $90 \%-95 \%$ in urban areas [9].

Hue city has 23 traditional markets with different scales. According to Government Decree No. 2/2003/NĐCP [10] on market development and management, 23 markets in Hue city are classified into three classes in terms of their scale, trade volume, and facility conditions. Among them, 3 markets belong to the first class, 6 markets belong to second class, and 14 markets belong to the third class. Markets sell widely diverse items such as food, vegetable, meat, clothes, and household equipment. There are businesses of two types in Hue, defined as follows.

> Stall: a shop selling goods at a designated place with a contract for a certain period of time, normally located inside a market building

$>$ Vendor: someone who is selling goods without contract for a certain period of time, normally located outside of market building

Stalls and vendors in markets generate waste of many kinds such as rubbish from commodities, containers and packaging. Some of them separate recyclable items for recycling markets and food residues for animal feed 
in Hue. For this study, the authors chose Tay Loc market from first class, Vy Da and Xep markets from second class, and Phuoc Vinh and Thong markets from third class as the target considering location and scale. An outline of the five markets is shown in Table 1. Markets have widely diverse business categories. Prime Minister of the Government of Vietnam (VPM, 2007) issued "The System of Economic Branches of Vietnam" [11] and defined the business category in 642 branches. By referring the official definition, the authors defined 17 business categories for market as shown in Table 2. For target selection, the authors allocated target kiosks and vendors to cover 17 business categories. The total number of samples is shown in Table 2.

\subsection{Outline of Survey}

The authors conducted three surveys for all target samples: a waste generation survey by actual measurement, a waste composition survey, and a questionnaire survey. Surveys on Tay Loc, Xep and Phuoc Vinh market were conducted during 3 - 12 September. Surveys on Vy Da and Thong market were conducted during 9 - 17 September. The waste generation survey was administered to acquire data on the amount of waste generation for 10 consecutive days. Of them, the first three days were spent for practice; the authors used the data for the latter seven consecutive days. The target stalls and vendors were requested to keep their waste in three categories by their original customs: "Recyclables", "Food residues" and "General waste", defined as follows.

$\checkmark$ Recyclables: items kept for recycling or sale to informal sectors or given to somewhere/someone by owners.

$\checkmark$ Food residues: waste items kept for livestock (e.g. pigs) feeding; generally collected by livestock breeders.

$\checkmark$ General waste: all remaining waste items excluding separated waste items described above. This type of waste is collected daily by an environmental company in Hue (HEPCO).

Table 1. Outline of five target markets.

\begin{tabular}{|c|c|c|c|c|c|}
\hline Name & Tay Loc & Vy Da & Хер & Phuoc Vinh & Thong \\
\hline Market class & $1^{\mathrm{st}}$ & $2^{\text {nd }}$ & $2^{\text {nd }}$ & $3^{\text {rd }}$ & $3^{\text {rd }}$ \\
\hline Number of cleanings & 4 & 2 & 1 & 2 & 1 \\
\hline Number of stalls & 682 & 280 & 365 & 179 & 112 \\
\hline Number of vendors & 168 & 21 & 75 & 34 & $3-5$ \\
\hline Number of target samples & 91 & 66 & 63 & 58 & 30 \\
\hline
\end{tabular}

Table 2. Definition of business category.

\begin{tabular}{|c|c|}
\hline ID & Business category \\
\hline 1 & Rice \& powder \\
\hline 2 & Meat and meat products \\
\hline 3 & Chicken \& Duck \\
\hline 4 & Eggs \\
\hline 5 & Fish \& fish products \\
\hline 6 & Vegetable \\
\hline 7 & Betel and areca \\
\hline 8 & Fruits \\
\hline 9 & Coconut \\
\hline 10 & Spice, Grocery, Cakes \& candy \\
\hline 11 & Food stalls \\
\hline 12 & Beverages \\
\hline 13 & Textiles, apparel, footwear \\
\hline 14 & Fresh flowers, ornamental plants \\
\hline 15 & Daily commodity, incense, porcelain \\
\hline 16 & Service (hair cutting, foot repairing) \\
\hline 17 & Recyclable, Second-hand clothes \\
\hline
\end{tabular}


A waste composition survey was also conducted during the survey period. To provide information related to the recycling and composting potentials, the authors analysed details of the waste composition of "General waste" for some representative targets. The waste was classified into 10 physical categories and 77 sub-categories. The classification categories were based on Materials (Plastic, Paper, Kitchen waste, Rubber \& Leather, Grass, Textile, Metal, Glass, Ceramic, and Miscellaneous), Types (Container/Packaging, Product and Other), Recycling potential (recyclable and non-recyclable), and Composting potential (compostable and non-compostable). The recycling potential was defined based on the practical trading status of recycling market in Hue city. Recyclable items contained plastic, paper, glass, metal, and textiles that can be bought and sold at a recycling market. The composting potential was defined based on the acceptable items of some composting plants. Organic wastes are divisible into compostable and non-compostable wastes. Compostable items consisted of vegetables, food residue, grass, leaves, flowers, egg shells, fish bones, fruit, and fruit skins. Non-compostable items consisted of coconut shells, hard bones of animal, seashells, bamboos, large tree branches, and wood products. In this study, non-recyclable items were all items that could not be recycled or composted. Descriptions of waste classification categories are presented in Table 3 . The authors also administered a questionnaire survey to assess attributes and the current status of businesses of target stalls and vendors.

\subsection{Analytical Procedure}

The authors calculated key statistics related to waste generation rates by business category. The authors also assessed the mean difference among market classes using analysis of variance (ANOVA). The waste composition by percentage (\%) was calculated according to the physical category and by recycling and composting potentials.

By multiplying the waste generation rate by stall/vendors by total number of stall/vendors in Hue, the authors estimated the total waste generation amount from traditional market in Hue. The authors also calculated the 95\% confidence interval of total waste generation amount from a Monte Carlo simulation (100,000 times) based on the mean and standard error of waste generation rate by business category. Monte Carlo simulations are used widely to assess error propagation for model parameters [12]. The authors inferred the sensitivity as a percentage of the contribution from each parameter to the variance of the final result [13].

\section{Results and Discussion}

\subsection{Waste Generation Rate of Traditional Markets}

\subsubsection{Waste Generation Rate by Stall/Vendor}

The waste generation rates of traditional market were calculated using business categories. Table 4 presented the mean and standard deviation of waste generation rate (g/stall/day) of stall in three market classes. Regarding the waste generation rate by business category, "Vegetable", "Fruits", "Beverage" and "Fresh flowers" were higher in all wastes, whereas "Rice", "Meat", "Service" and "Second-hand shop" were identified as having lower generation rates. The result resembled that reported from a previous study by Byer et al. [4]. They reported that "Fruits and vegetables" generated the largest amount (6.49 kg/day) because of their high moisture contents.

Regarding fresh items that are easily be perishable after 1 - 2 days under normal conditions such as "Meat \& meat product", "Chicken \& duck", "Fish \& fish product", "Vegetable", "Fruit", "Fresh flowers", the category of "Meat \& meat product" generated the smallest amount with 289 (g/stall/day), whereas the other categories generated much higher waste amounts. In the category of "Vegetable" and "Fruit", even though the total waste amount was rather large, the amounts of food residues were quite small because the rotten or leftover vegetables and fruits were normally unsuitable for feeding animals. Conversely, the categories of "Chicken \& duck", "Fish $\&$ fish product" generated a large amount of food residues because these categories had processing services on site. Therefore, normally the internal organs and unnecessary parts were separated as food residues.

Some dry-food items such as "Rice/powder" and "Spice and grocery" produced smaller amounts with 110 and 759 (g/stall/day), respectively. Regarding food services, "Food stalls” \& "Beverage” respectively produced similar total waste amounts, with 3525 and 3323 (g/stall/day). However, "Beverage” generated small amounts of food residues, whereas a major amount of wastes in "Food stalls" were food residues. Table 4 also shows that some business categories such as "Meat", "Chicken \& Duck", "Fish", "Vegetable”, and "Fresh flowers" did not separate recyclables. Table 5 presents the mean and standard deviation of waste generation rate (g/vendor/day) 
Table 3. Classification category of waste from market.

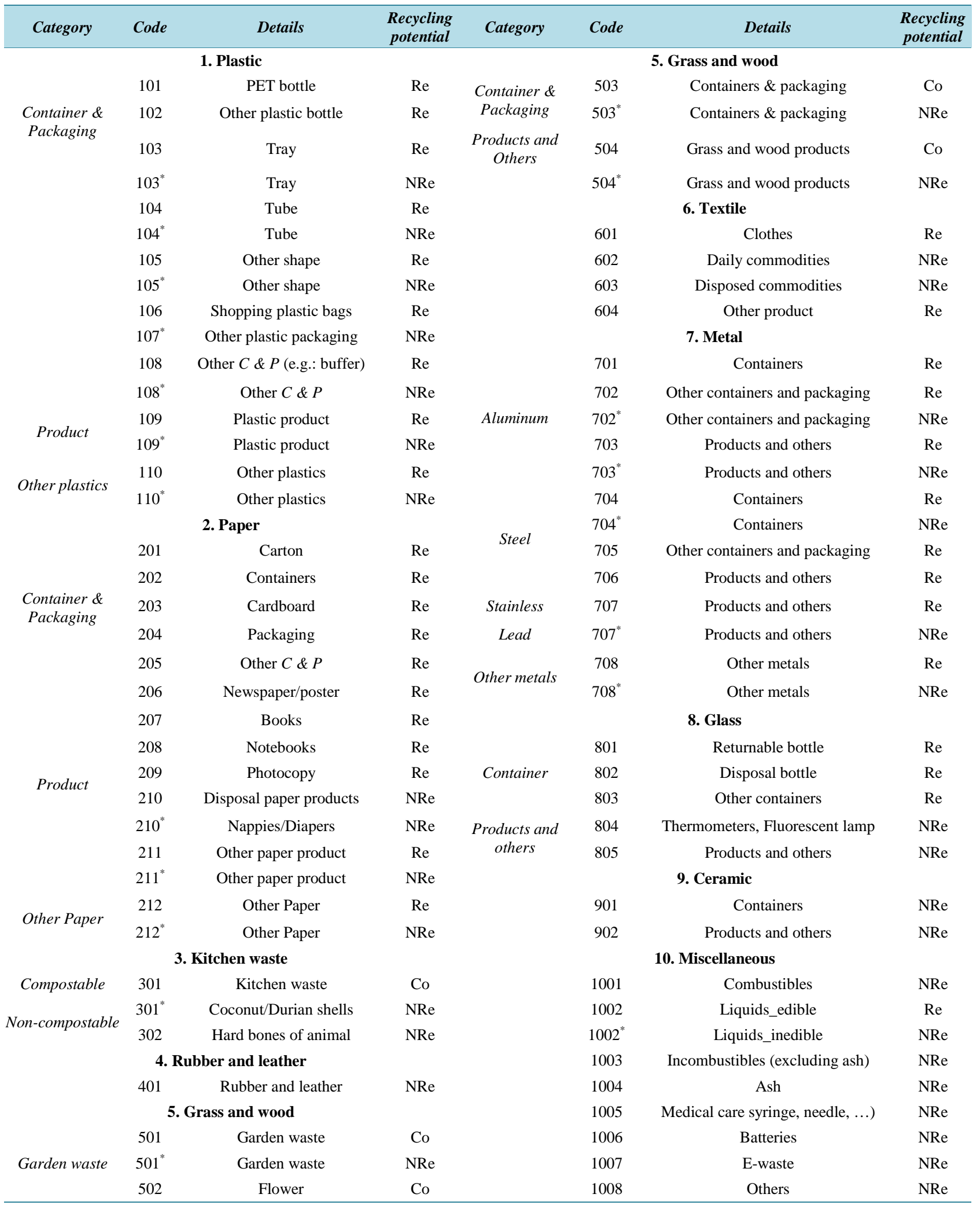

${ }^{a}$ Re, Recyclable; Co, Compostable; NRe, Non-recyclable \& non-compostable items, The recycling potential of each item was defined based on reports from two junk-shop owners. The compostable item and non-compostable item were defined based on the acceptable items in some composting plants. 
Table 4. Waste generation rate by stall (g/stall/day).

\begin{tabular}{|c|c|c|c|c|c|}
\hline \multirow{2}{*}{ Category } & \multirow{2}{*}{$N$} & General waste & Recyclable & Food residues & Total waste \\
\hline & & \multicolumn{4}{|c|}{ Mean \pm Standard deviation } \\
\hline Rice, powder & 6 & $89 \pm 89$ & $8 \pm 20$ & $13 \pm 31$ & $110 \pm 95$ \\
\hline Meat/meat product & 13 & $268 \pm 305$ & - & $20 \pm 40$ & $289 \pm 299$ \\
\hline Chicken \& duck & 12 & $102 \pm 165$ & - & $2664 \pm 3264$ & $2766 \pm 3194$ \\
\hline Egg & 4 & $445 \pm 644$ & $291 \pm 314$ & - & $737 \pm 555$ \\
\hline Fish \& fish product & 32 & $248 \pm 269$ & - & $2513 \pm 2445$ & $2761 \pm 2486$ \\
\hline Vegetable & 40 & $4893 \pm 5525$ & - & $250 \pm 727$ & $5143 \pm 5657$ \\
\hline Betel \& areca & 2 & $1138 \pm 597$ & $140 \pm 37$ & - & $1278 \pm 634$ \\
\hline Fruit & 31 & $3865 \pm 2921$ & $520 \pm 853$ & $184 \pm 1023$ & $4568 \pm 3343$ \\
\hline Spice \& Grocery & 37 & $392 \pm 866$ & $149 \pm 301$ & $218 \pm 939$ & $759 \pm 1342$ \\
\hline Food stall & 21 & $762 \pm 717$ & $9 \pm 42$ & $2754 \pm 3594$ & $3525 \pm 3801$ \\
\hline Beverages & 10 & $2829 \pm 3023$ & $170 \pm 271$ & $324 \pm 1023$ & $3323 \pm 2955$ \\
\hline Textiles \& Apparel & 16 & $195 \pm 157$ & $43 \pm 166$ & - & $238 \pm 242$ \\
\hline Fresh flowers & 11 & $3209 \pm 4009$ & - & - & $3209 \pm 4009$ \\
\hline Daily commodity & 18 & $271 \pm 283$ & $182 \pm 514$ & - & $453 \pm 566$ \\
\hline Service & 14 & $190 \pm 114$ & $8 \pm 27$ & - & $198 \pm 116$ \\
\hline Second-hand shop & 4 & $292 \pm 491$ & $124 \pm 152$ & - & $416 \pm 409$ \\
\hline
\end{tabular}

Table 5. Waste generation rate by vendor (g/vendor/day).

\begin{tabular}{|c|c|c|c|c|c|}
\hline \multirow{2}{*}{ Category } & \multirow{2}{*}{$\mathbf{N}$} & General waste & Recyclable & Food residues & Total waste \\
\hline & & \multicolumn{4}{|c|}{ Mean \pm Standard deviation } \\
\hline Rice, powder_vendor & 1 & 268 & - & - & 268 \\
\hline Egg_vendor & 2 & $412 \pm 197$ & - & - & $412 \pm 197$ \\
\hline Fish \& fish product_vendor & 2 & - & - & $1628 \pm 462$ & $1628 \pm 462$ \\
\hline Vegetable_vendor & 11 & $3918 \pm 3117$ & - & $88 \pm 212$ & $4006 \pm 3039$ \\
\hline Betel and areca_vendor & 2 & $4226 \pm 4848$ & - & - & $4226 \pm 4848$ \\
\hline Fruit_vendor & 7 & $1811 \pm 1911$ & $71 \pm 123$ & - & $1882 \pm 1867$ \\
\hline Coconut_vendor & 2 & $91801 \pm 1040$ & - & - & $91801 \pm 1040$ \\
\hline Spice \& Grocery_vendor & 3 & $291 \pm 375$ & - & - & $291 \pm 375$ \\
\hline Food stall_vendor & 5 & $493 \pm 418$ & - & $876 \pm 1206$ & $1369 \pm 868$ \\
\hline Textiles \& Apparel_vendor & 1 & 23 & - & - & 23 \\
\hline Fresh flowers_vendor & 2 & $1451 \pm 84$ & - & - & $1451 \pm 84$ \\
\hline
\end{tabular}

of vendors in three market classes. The "Coconut_vendor" category was separated from "Fruit_vendor” because the waste generation rate of “Coconut_vendor” was extremely high, with 91,801 g/day, which was much higher than that of “Fruit_vendor" with 1882 g/vendor/day.

Comparing the waste generation rate of a stall with that of a vendor, some categories with higher waste generation rates such as "Fish \& fish product", "Vegetable_vendor", "Fruit”, "Food stall” and "Fresh flowers", the waste generation rate of a stall was higher than that of a vendor. That result is explainable that the space and business scale of vendors were normally smaller than those of stalls; the resultant waste generation rate was lower. The vendors did not separate recyclables in most business categories excluding "Fruit_vendor"; the food 
residue amount was small excluding "Fish_vendor" and "Food_vendor" as stalls, probably because they had insufficient space to keep such wastes.

\subsubsection{Waste Generation Rate by Floor Area}

In the traditional market, the stall areas differ among market classes and business categories. The authors calculated the waste generation rate by floor area for two markets for which the managers of markets provided the official data on floor area of each stall, Tay Loc as a first class market and Xep as a second class market. Table 6 presents the means and standard deviations of waste generation rate of 17 business categories by floor area $\left(\mathrm{g} / \mathrm{m}^{2} /\right.$ day) in two markets. The floor areas in most business categories in the first class market were larger than those of the second class market. For "Rice \& powder", "Fish \& fish product", "Vegetable", "Spice \& Grocery", "Beverage", "Textile \& Apparel", "Fresh Flowers", "Daily commodity" and "Service" categories, the waste generation rate of total waste by square meter was higher for the first class market than for the second class market. For "Meat \& meat product", "Fruit" and "Food stall" categories, the waste generation rate of total waste by square meter was higher for the second class market, but the waste generation rate of total waste by stall was higher for the first class market.

In most of business categories, the stalls in first class market discharged more waste than those in the second class. In the first class market, no stalls existed for "Egg" and "Betel \& areca" categories. These items were sold only at vendors in the first class market. Regarding the "Chicken \& duck" category, the waste generation rate of total waste by square meter in the first class market was $178 \mathrm{~g} / \mathrm{m}^{2} /$ day, which was much lower than that in the second class market at $2090 \mathrm{~g} / \mathrm{m}^{2} /$ day. By the observation in both markets, the difference noted above can be explained by the habit of stall owner in keeping internal organs of "Chicken \& duck" in each market. In the first class market, the owners generally separated internal organs and sold them to customers, whereas the owners in the second class market normally put internal organs into containers as food residues for livestock breeders and occasionally sold them to customers upon request.

Table 6. Waste generation rate by floor area.

\begin{tabular}{|c|c|c|c|c|c|c|c|c|c|c|}
\hline \multirow{3}{*}{ Category } & \multicolumn{5}{|c|}{ Tay Loc } & \multicolumn{5}{|c|}{ Хер } \\
\hline & \multirow{2}{*}{$\begin{array}{c}\text { Area } \\
\mathbf{m}^{2}\end{array}$} & GW & $\mathbf{R e}$ & FR & Total & \multirow{2}{*}{$\begin{array}{c}\text { Area } \\
\mathbf{m}^{2}\end{array}$} & GW & $\mathbf{R e}$ & FR & Total \\
\hline & & \multicolumn{4}{|c|}{$\mathrm{g} / \mathrm{m}^{2} /$ day } & & \multicolumn{4}{|c|}{$\mathrm{g} / \mathrm{m}^{2} /$ day } \\
\hline Rice \& powder & 3.2 & $42 \pm 24$ & $8 \pm 11$ & - & $49 \pm 34$ & 1.69 & 1 & 1 & - & 2 \\
\hline Meat \& meat product & 2 & $250 \pm 247$ & - & - & $250 \pm 247$ & 1.69 & $272 \pm 266$ & - & - & $272 \pm 266$ \\
\hline Chicken \& duck & 3.6 & - & - & $178 \pm 7$ & $178 \pm 7$ & 2.25 & $40 \pm 63$ & - & $2050 \pm 1670$ & $2090 \pm 1622$ \\
\hline Egg & - & - & - & - & - & 2.25 & $338 \pm 408$ & $167 \pm 189$ & - & $505 \pm 218$ \\
\hline Fish \& fish product & 3.6 & $126 \pm 115$ & - & $1209 \pm 913$ & $1335 \pm 940$ & 1.69 & $163 \pm 164$ & - & $739 \pm 925$ & $903 \pm 861$ \\
\hline Vegetable & $3.6-10.8$ & $2274 \pm 1531$ & - & $49 \pm 63$ & $2324 \pm 1518$ & $1.69-3.38$ & $964 \pm 575$ & - & $78 \pm 100$ & $1042 \pm 557$ \\
\hline Betel \& areca & - & - & - & - & - & 2.25 & 693 & 74 & - & 767 \\
\hline Fruit & 3.6 & $1248 \pm 857$ & - & - & $1248 \pm 857$ & $1.69-3.38$ & $1362 \pm 886$ & $402 \pm 625$ & $211 \pm 596$ & $1975 \pm 1288$ \\
\hline Spice \& Grocery & $2-6.4$ & $73 \pm 47$ & $80 \pm 129$ & - & $153 \pm 159$ & $2.25-4.5$ & $23 \pm 12$ & $73 \pm 90$ & - & $96 \pm 86$ \\
\hline Food stall & $3.6-7.2$ & $199 \pm 207$ & - & $1085 \pm 1030$ & $1283 \pm 949$ & $2.25-4.5$ & $353 \pm 351$ & $14 \pm 35$ & $1252 \pm 2149$ & $1619 \pm 2464$ \\
\hline Beverages & 3.6 & $2095 \pm 235$ & $69 \pm 11$ & - & $2163 \pm 246$ & $2.25-4.5$ & $397 \pm 400$ & $147 \pm 69$ & - & $544 \pm 469$ \\
\hline Textiles \& Apparel & $3.6-12$ & $66 \pm 38$ & - & - & $66 \pm 38$ & 4.5 & $13 \pm 9$ & - & - & $13 \pm 9$ \\
\hline Fresh flower & $3.6-7.2$ & $1224 \pm 1465$ & - & - & $1224 \pm 1465$ & $2.25-7.29$ & $444 \pm 269$ & - & - & $444 \pm 269$ \\
\hline Daily commodity & $2-4$ & $125 \pm 126$ & $29 \pm 64$ & - & $154 \pm 182$ & $1.69-14.58$ & $83 \pm 70$ & $4 \pm 7$ & - & $88 \pm 73$ \\
\hline Service & $2-3.6$ & $53 \pm 22$ & - & - & $53 \pm 22$ & 7.29 & 23 & 14 & - & 37 \\
\hline Second-hand shop & 3.2 & $91 \pm 153$ & $39 \pm 48$ & - & $130 \pm 128$ & - & - & - & - & - \\
\hline
\end{tabular}

GW, General waste; Re, Recyclable; FR, Food residue. 


\subsection{Mean Difference in Waste Generation Rate by Market Class}

Regarding comparison among three market classes, the authors assessed the mean difference in waste generation rates among the three market classes by 17 business categories using ANOVA. The authors found significant mean differences for "Fish" and "Vegetable". Table 7 shows means and SDs of waste generation rates for "Fish" and "Vegetable" by three market classes and ANOVA results. The waste generation rate was the highest in the first class, and lower in the second class and the third class. The differences among three markets are explainable by the fact obtained from questionnaire survey that, in the first class market, the area was largest and the operation time was very long, whereas the area and operation time were smaller in the second and third class markets, which can be expected to influence the amounts of sales and waste generation.

\subsection{Waste Composition of Market}

\subsubsection{Physical Composition}

The physical composition of general waste by business category is shown in Table 8 . The physical composition differs among business categories. The results indicated that food waste accounts for the largest part with sub-

Table 7. Waste generation rate by market class (g/stall/day).

\begin{tabular}{|c|c|c|c|c|c|}
\hline Category & $\begin{array}{c}\text { Market } \\
\text { class }\end{array}$ & $N$ & General waste & Food residues & Total waste \\
\hline \multirow{3}{*}{ Fish \& fish product } & 1 & 7 & $452 \pm 412$ & $4352 \pm 3288$ & $4804 \pm 3384$ \\
\hline & 2 & 14 & $207 \pm 224$ & $1428 \pm 1095$ & $1635 \pm 1018$ \\
\hline & 3 & 11 & $169 \pm 137$ & $2725 \pm 2533$ & $2894 \pm 2493$ \\
\hline \multicolumn{3}{|c|}{ ANOVA ( $F$ value) } & 3.001 & $4.077^{*}$ & $4.74^{*}$ \\
\hline \multirow{3}{*}{ Vegetable } & 1 & 9 & $11785 \pm 7877$ & $340 \pm 564$ & $12125 \pm 8134$ \\
\hline & 2 & 14 & $2928 \pm 2757$ & $199 \pm 358$ & $3127 \pm 2996$ \\
\hline & 3 & 17 & $2863 \pm 1653$ & $245 \pm 1009$ & $3108 \pm 1504$ \\
\hline \multicolumn{3}{|c|}{ ANOVA ( $F$ value) } & $15.972^{* * *}$ & 0.098 & $15.351^{* * *}$ \\
\hline
\end{tabular}

${ }^{*} \mathrm{p}<0.05 ;{ }^{* *} \mathrm{p}<0.01 ;{ }^{* * *} \mathrm{p}<0.001$.

Table 8. Physical composition by business category (\%).

\begin{tabular}{|c|c|c|c|c|c|c|c|c|c|c|c|}
\hline ID & $N$ & Plastic & Paper & Food & Rubber & Grass & Textile & Metal & Glass & Ceramic & Other \\
\hline Rice, powder & 6 & $6.8 \%$ & $0.7 \%$ & $52.6 \%$ & $0.1 \%$ & $21.5 \%$ & - & - & - & - & $18.3 \%$ \\
\hline Meat & 15 & $48.2 \%$ & $0.9 \%$ & $44.8 \%$ & - & $2.9 \%$ & - & - & - & - & $3.3 \%$ \\
\hline Chicken \& duck & 2 & $51.8 \%$ & $9.9 \%$ & $24.4 \%$ & $11.3 \%$ & $1.5 \%$ & - & $1.0 \%$ & - & - & - \\
\hline Egg & 7 & $9.4 \%$ & $2.1 \%$ & $67.8 \%$ & - & $20.5 \%$ & - & - & - & - & $0.1 \%$ \\
\hline Fish & 30 & $32.6 \%$ & $0.2 \%$ & $45.1 \%$ & - & $4.7 \%$ & - & - & - & - & $17.4 \%$ \\
\hline Vegetable & 17 & $2.8 \%$ & $0.3 \%$ & $93.2 \%$ & - & $1.3 \%$ & - & - & - & - & $2.4 \%$ \\
\hline Betel \& areca & 2 & $2.2 \%$ & $0.1 \%$ & $14.7 \%$ & - & $83 \%$ & - & - & - & - & - \\
\hline Fruit & 14 & $1.6 \%$ & $3.5 \%$ & $81.7 \%$ & $0.1 \%$ & $12.7 \%$ & - & - & - & - & $0.3 \%$ \\
\hline Spice \& Grocery & 33 & $26.4 \%$ & $14.7 \%$ & $52.5 \%$ & $1.6 \%$ & $2.2 \%$ & $0.1 \%$ & $0.5 \%$ & - & - & $2 \%$ \\
\hline Food stalls & 25 & $7.4 \%$ & $8.3 \%$ & $25 \%$ & $0.2 \%$ & $51.9 \%$ & $2.9 \%$ & - & - & - & $4.3 \%$ \\
\hline Beverages & 8 & $8.1 \%$ & $0.1 \%$ & $77.2 \%$ & - & $8.6 \%$ & - & - & - & - & $6.1 \%$ \\
\hline Textiles \& footwear & 13 & $40 \%$ & $15.1 \%$ & $20.3 \%$ & $21.2 \%$ & - & $0.7 \%$ & $2.1 \%$ & - & - & $0.5 \%$ \\
\hline Fresh flowers & 6 & $2.1 \%$ & $1.7 \%$ & $21.7 \%$ & - & $74.5 \%$ & - & - & - & - & - \\
\hline $\begin{array}{l}\text { Daily commodity } \\
\text { Daily commodity }\end{array}$ & 11 & $10.4 \%$ & $12.7 \%$ & $62.3 \%$ & $0.2 \%$ & $3.8 \%$ & $2.3 \%$ & $0.1 \%$ & - & $8.0 \%$ & $0.1 \%$ \\
\hline Service & 5 & $30.1 \%$ & $2.4 \%$ & $31.6 \%$ & $0.1 \%$ & $2.4 \%$ & $11.6 \%$ & $0.8 \%$ & - & - & $21 \%$ \\
\hline Second-hand shop & 2 & $29.0 \%$ & $69.5 \%$ & - & - & - & - & - & - & - & $1.4 \%$ \\
\hline
\end{tabular}


sequent plastic or grass. The proportions of food waste were high, with $93.2 \%, 81.7 \%$ and $77.2 \%$, respectively, in "Vegetable", "Fruit" and "Beverage". Previous reports have described that the major portion of solid waste in market is food waste and other organic matter. A survey conducted in Danang [6] reported that the organic part accounted for $81.5 \%$. A survey in Thailand also presented that the organic from market was 85\% [14].

The categories of "Meat", "Fish", "Textile" and "Spice" generated plastics with higher percentage, using mainly single-use plastic bags for packaging, whereas "Betel \& areca", "Fresh flower" and "Food stalls" categories generated grass with higher percentages. These results directly reflected the fact that some parts of "Betel and areca" and "Fresh flower" such as stems, leaves, and un-needed parts are often removed according to requests from customers. "Food stalls" generated large amounts of grass because Vietnamese people have a habit of wrapping some foods in leaves such as banana or lotus leaves. They discard them after use. Glass was not found in all categories, and ceramic was only found in "Daily commodity" with 8\%. Rubber was found in "Chicken \& duck" because rubber bands are usually used to tie live chicken or duck legs. The "Textiles \& footwear" category generated some rubber because rubber pieces were often used to repair shoes.

\subsubsection{Recycling and Composting Potential of Waste from Traditional Markets}

Table 9 presents waste composting and recycling potentials from general waste by business category according to the definition shown in Table 3. It is apparent that the composting potential was very high in some categories such as "Betel \& areca", "Vegetable", "Fruit" and "Fresh flowers". The recycling potential was highest in the category of "Second-hand shop" with $98.6 \%$ followed by "Textiles \& apparel" with 63.6\%, "Meat" with 48.9\% and "Chicken \& duck" with $46.4 \%$.

\subsection{Estimation of Total Waste Generation from Traditional Market in Hue}

\subsubsection{Validation of General Waste at Three Markets}

To validate waste generation rates in Table 4 and Table 5, the authors estimated the 95\% confidence intervals (CIs) of total amount of general waste for three target markets, Tay Loc in the first class, Xep in the second class and Phuoc Vinh in the third class, and compared the CIs with the measured waste amounts by actual measurement on site. By multiplying the waste generation rate by the stall/vendor by total number of stall/vendor in target markets, the authors calculated the total amounts of general wastes for the target markets. The $95 \%$ confidence interval for each market was estimated using Monte Carlo simulation (100,000 times) based on the mean and standard error of the waste generation rates shown in Table 4 and Table 5 . Table 10 presents the 95\% CIs

Table 9. Recycling and composting potential of general waste (\%).

\begin{tabular}{|c|c|c|c|c|}
\hline Category & $\mathbf{N}$ & Non-recyclable & Recyclable & Compostable \\
\hline Rice/powder & 6 & $18.1 \%$ & $6.4 \%$ & $75.5 \%$ \\
\hline Meat & 15 & $8.7 \%$ & $48.9 \%$ & $42.4 \%$ \\
\hline Chicken \& duck & 2 & $26.1 \%$ & $46.4 \%$ & $27.5 \%$ \\
\hline Egg & 7 & $3.0 \%$ & $10.5 \%$ & $86.6 \%$ \\
\hline Fish & 30 & $18.0 \%$ & $32.3 \%$ & $49.7 \%$ \\
\hline Vegetable & 17 & $2.8 \%$ & $2.9 \%$ & $94.3 \%$ \\
\hline Betel \& areca & 2 & $1 \%$ & $1.3 \%$ & $97.7 \%$ \\
\hline Fruit & 14 & $3.8 \%$ & $4.1 \%$ & $92.1 \%$ \\
\hline Spice \& Grocery & 33 & $8.7 \%$ & $37.8 \%$ & $53.5 \%$ \\
\hline Food stalls & 25 & $14.4 \%$ & $9.5 \%$ & $76.1 \%$ \\
\hline Beverages & 8 & $6.2 \%$ & $8.2 \%$ & $85.7 \%$ \\
\hline Textiles \& footwear & 13 & $11.9 \%$ & $63.6 \%$ & $24.4 \%$ \\
\hline Fresh flower & 6 & $2.7 \%$ & $2.7 \%$ & $94.5 \%$ \\
\hline Daily commodity & 11 & $14.5 \%$ & $21.4 \%$ & $64.1 \%$ \\
\hline Service & 5 & $34.6 \%$ & $24.7 \%$ & $40.7 \%$ \\
\hline Second-hand shop & 3 & $1.4 \%$ & $98.6 \%$ & $0.0 \%$ \\
\hline
\end{tabular}


Table 10. Interval estimation of three markets and actual amount.

\begin{tabular}{ccc}
\hline Market & 95\% CI of general waste (kg) & Actual amount (kg) \\
\hline Tay Loc market & $1412-2163$ & 1766 \\
Xep market & $286-502$ & 473.8 \\
Phuoc Vinh market & $252-363$ & 343.5 \\
\hline
\end{tabular}

of general waste (kg/day) and the measured waste amounts in three markets. The results show that the measured waste amounts were in the $95 \%$ CI range for the three markets.

\subsubsection{Total Waste Generation from Traditional Markets}

Hue city has 23 traditional markets. Because of a lack of information exists for the floor area by each business categories in 23 markets, in this study, the author used only the number of stalls by business category as an indicator for estimation the total amount of waste from traditional market in Hue. By multiplying the waste generation rate by stall/vendor by the total number of stall/vendors in 23 markets, the authors calculated the total amount of general waste, recyclable, food residue, and total waste by business category. The general waste also included some amount of recyclable and compostable parts, as shown in Table 8 . The authors also estimated the potentials of recycling and composting in general waste separately.

Table 11 presents details of waste generation from a traditional market in Hue: non-recyclable, recycling potential, composting potential contained in general waste: recyclable, food residues, and total waste by weight (kg/day) by business category. The total waste generation amount was 17.0 tons, of which $3.6 \%$ of waste was separated at the source as recyclable, $69.2 \%$ was general waste, and $27.1 \%$ was food residues. In general waste, the recycling potential accounted for $5.1 \%$, composting potential accounted for $55.2 \%$, and the remaining waste accounted for only $8.8 \%$. This result indicates that waste generation in markets has high potential up to $82.3 \%$ of total for composting and livestock feeding.

The total disposal amount sent to the landfill site can be reduced from $69.2 \%$ to $8.8 \%$. Regarding the "Coconut" category, the waste generation rate was the highest with $91.8 \mathrm{~kg} / \mathrm{stall} /$ day and was mainly composed of coconut shell. Therefore, we did not bring it to the laboratory to examine the composition. The authors assumed that the total generated waste from the "Coconut" category was non-recyclable. Regarding composting potential, "Vegetable” accounted for the largest amount with $4422 \mathrm{~kg} / \mathrm{day}$, followed by "Vegetable_vendor”, (1580 kg/day) and "Fruit" (1520 kg/day). These results suggest that these sources would contribute immensely to promoting waste reduction. Regarding about the recycling potential, the largest contribution category was "Spice \& grocery" with 195 kg/day, followed by “Vegetable” (135 kg/day), “Textiles \& apparel” (120 kg/day), “Fish” (86 kg/day), and "Meat" (83 kg/day). The results revealed that these categories should be considered heavily for promotion for recycling for market. The total estimated composting potential was 9.4 tons, which contributes mostly to the total general waste in the market. The large quantity of composting potential present in the MSW stream has a great impact on the production of high-quality compost and offers great potential for resource recovery. Such recovery is expected to play an important role in reducing total waste generation amount and in mitigating the negative effects on environmental quality and natural resource conservation.

\subsubsection{Interval Estimation of Total Waste Generation from Traditional Market in Hue}

The 95\% confidence interval (CI) of total waste amount from 23 markets was also estimated using Monte Carlo simulation (100,000 times) based on the mean and standard error of waste generation rate shown in Table 4 and Table 5. The results showed that the range of 95\% CI was 14.9 - 18.9 tons/day.

The authors also examined the sensitivity as a percentage of the contribution from the waste generation rate of each business category to the variance of the total waste amount. Figure 1 presents the result of sensitivity analysis. "Vegetables of first class market" was identified as the category with the largest contribution (34.8\%) to the variance of the total waste amount, followed by "Vegetable_vendor" (13.5\%) and "Fish of first class", (10.9\%). To improve the reliability of total estimation, the sample size should be increased. Further investigation must be undertaken to clarify the factors affecting waste generation rate in these categories.

\section{Conclusions}

1) This study produced a detailed description of waste generation and composition by 17 business categories 
Table 11. Waste amounts by business category from 23 markets in Hue (kg/day).

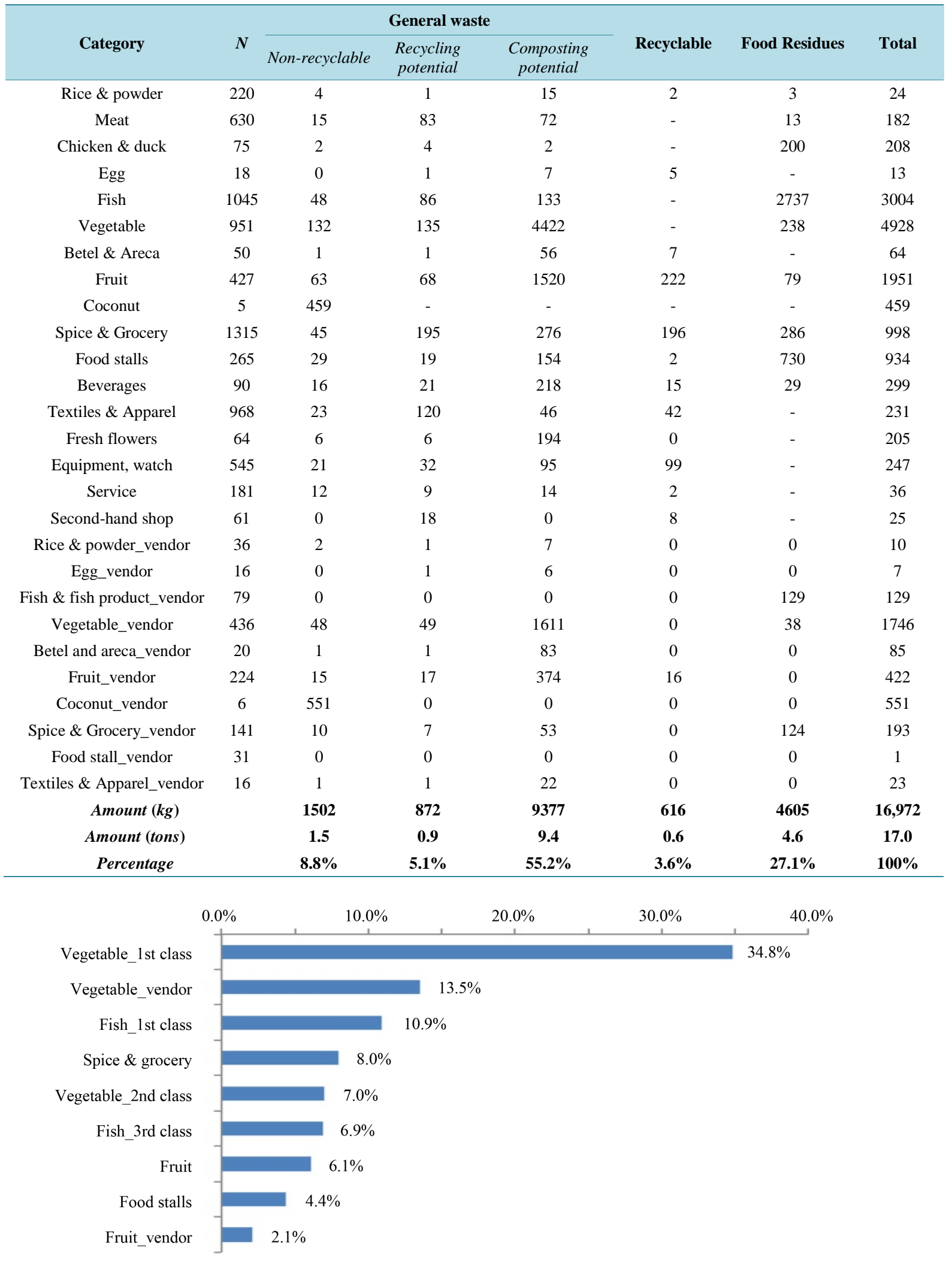

Figure 1. Sensitivity analysis of total waste generation. 
in a traditional market in Hue city, Vietnam. In all, 309 stalls/vendors in five markets were surveyed for 10 consecutive days in the dry season.

2) The waste generation rate by stall/vendor was assessed by each business category by three waste categories: general waste, recyclable, food residues. The waste generation rates of "Vegetable", "Fruits", "Beverage" and "Fresh Flowers" were higher in all wastes, whereas those of "Rice", "Meat", "Service" and "Second-hand shop" were identified as having lower generation rates.

3) Significant mean differences of total waste amount were found in "Fish" and "Vegetable" categories. The waste generation rate was the highest in the first market class and lower in the second market class and third market class.

4) The waste generation rate by floor area was also calculated in two markets in first and second classes. In most business categories, the stalls in the first class market discharged more waste than those in the second class.

5) The general waste was classified into 10 physical categories and 77 sub-categories. Food waste accounted for the largest part, followed by plastic and grass. The results from sub-categories demonstrated the potential for composting and recycling.

6) As the validation of waste generation rate, the authors estimated the $95 \%$ confidence intervals (CIs) of total amount of general waste for three target markets and compared the CIs with the measured waste amounts by actual measurements conducted on site. The measured waste amounts were in the $95 \% \mathrm{CI}$ range for the three markets.

7) The authors also estimated the total generated waste, the recycling and composting potential for 23 traditional markets in Hue. The total waste generated from market was 17.0 tons/day, of which 4.6 tons (27.1\%) was collected by pig farmers for feeding livestock and 0.6 tons (3.6\%) was sold to the recycling market. The composting potential accounted for $55.2 \%$ and the recycling potential accounted for $5.1 \%$ of total waste generation from traditional market in Hue. The total disposal amount sent to the landfill site would be reduced from $69.2 \%$ to $8.8 \%$ of the total.

By the Monte Carlo simulation, the confidence interval of total waste generation from traditional market in Hue was estimated. The 95\% CI of total waste was 14.9 - 18.9 tons/day. By sensitivity analysis, "Vegetable of first class market" was identified as the category with the largest contribution to the variance of the total waste amount with subsequent "Vegetable_vendor" and "Fish of first class". To improve the reliability of total estimation, the sample size should be increased and further investigation is necessary to clarify the factors affecting waste generation rates in these categories.

\section{Acknowledgements}

The authors sincerely thank the staff and students from Hue University for their assistance in this study. Special thanks to Dr. Pham Khac Lieu and Mr. Tran Ngoc Tuan who supported our survey enthusiastically. The authors also express their appreciation to the statistical office in Hue as well as all of stall/vendor owners in five target markets for collaborating with us.

\section{References}

[1] World Bank, MoNRE and CIDA (2004) Vietnam Environment Monitor. 65.

[2] Forbes, R.M., Peter, R.W., Marian, F. and Peter, H. (2001). Integrated Solid Waste Management: A Life Cycle Inventory. Second Edition, Blackwell Science, Oxford.

[3] Meidiana, C. and Gamse, T. (2010) Development of Waste Management Practices in Indonesia. European Journal of Scientific Research, 40, 199-210.

[4] Byer, P.H., Hoang, C.P., Nguyen, T.T.T., Chopra, S., Maclaren, V. and Haight, M. (2006) Household, Hotel and Market Waste Audits for Composting in Vietnam and Laos. Waste Management \& Research, 24, 465-472. http://dx.doi.org/10.1177/0734242X06068067

[5] JICA and Kokusai Kogyu Co. Ltd. (2003) The Study on Solid Waste Management in the Municipality of Phnom Penh.

[6] Otoma, S., Hoang, H., Hong, H., Miyazaki, I. and Diaz, R. (2013). A Survey on Municipal Solid Waste and Residents' Awareness in Da Nang City, Vietnam. Journal of Material Cycles Waste Management, 15, 187-194. http://dx.doi.org/10.1007/s10163-012-0109-2

[7] http://hueimperialcity.com/hue-introduction/ 
[8] Hue Statistical Yearbook (2012) Statistical Yearbook, Hue city’s Statistical Office, Hue, Vietnam.

[9] HEPCO (2011) Report on Solid Waste Management of Hue City. Hue Urban Environment and Public Works State Company (HEPCO). (In Vietnamese)

[10] Government Decree No. 2/2003/NĐ-CP on Market Development and Management.

[11] Vietnam's Prime Minister (VPM) Decision 10-2007-QD-TTg of the Prime Minister: The System of Economic Branches of Vietnam, Dated 23 January 2007, Prime Minister of the Government of Vietnam. Obtained through the Internet: http://vbqppl.moj.gov.vn/

[12] Huijbregts, M.A.J., Gilijamse, W., Ragas, A.M.J. and Reijnders, L. (2003) Evaluating Uncertainty in Environmental Life-Cycle Assessment. A Case Study Comparing Two Insulation Options for a Dutch One-Family Dwelling. Environmental Science \& Technology, 37, 2600-2608. http://dx.doi.org/10.1021/es020971+

[13] Sonnemann, G.W., Schuhmacher, M. and Castells, F. (2003) Uncertainty Assessment by a Monte Carlo Simulation in a Life Cycle Inventory of Electricity Produced by Using a Waste Incinerator. Journal of Cleaner Production, 11, 279292. http://dx.doi.org/10.1016/S0959-6526(02)00028-8

[14] Ali, G., Nitivattananon, V., Abbas, S. and Sabir, M. (2012) Green Waste to Biogas: Renewable Energy Possibilities for Thailand's Green Markets. Renewable and Sustainable Energy Reviews, 16, 5423-5429. http://dx.doi.org/10.1016/j.rser.2012.05.021 